\title{
The Capability of Canna edulis Ker Starch as Carboxymethyl Cellulose Replacement on Yogurt Drink During Cold Storage
}

\author{
Ahmad Khoirul Umam ${ }^{1 *}$, Mei-Jen Lin ${ }^{2}$, Lilik Eka Radiati ${ }^{1}$ and Shao-Yu Peng ${ }^{2}$ \\ ${ }^{1}$ Faculty of Animal Husbandry, Brawijaya University Jl. Veteran, Malang 65145, Indonesia \\ 2Department of Animal Science, National Pingtung University of Science and Technology, 1, Shuefu Road, Neipu, \\ Pingtung 91201, Taiwan \\ *Corresponding author: a.khoirulumam@ub.ac.id
}

\begin{abstract}
A yogurt drink storing process will directly affect the decrease of product quality. Stabilizer that usually used for maintaining the yogurt quality is a chemical compound namely carboxymethyl cellulose (CMC). Canna (Canna edulis Ker) potentially used as a natural stabilizer, which is a local Indonesian tuber with high starch content and antioxidative properties. The purpose of this study is to investigate the capability of Canna starch to replace the used of CMC based on the physicochemical and antioxidant activity of yogurt drink during cold storage. The complete randomized factorial design will be used with two factors. The first factor was Canna starch/CMC levels divided into 5 groups, T0 $(0.2 \% \mathrm{CMC})$ as a control, T1 $(0.15 \% \mathrm{CMC}+0.025 \%$ canna), T2 (0.1\% CMC + 0.05\% canna), T3 (0.05\% CMC + 0.075\% canna), and T4 (0.1\% Canna), respectively. The second factor was the storage time of yogurt drink divided into four groups, 1, 7, 14 and 21 days, to determine the quality change during stored in the refrigerator at $4^{\circ} \mathrm{C}$. Data obtained from the results of subsequent studies analyzed by GLM (General Linear Model) and followed by Duncan's multiple range test (DMRT). This study resulted that Canna starch has the capability as a natural stabilizer for producing new yogurt drink product as the functional beverage with potential health benefits related to the high antioxidant activity. The combination of $0.1 \% \mathrm{CMC}$ and $0.05 \%$ Canna starch addition on yogurt drink manufacture showed the best physicochemical quality including $\mathrm{pH}$, titratable acidity, syneresis, sedimentable fraction, and viscosity.

Keywords : antioxidant activity, Canna edulis Ker, carboxymethyl cellulose, Syneresis, Viscosity
\end{abstract}

Abstrak. Proses penyimpanan akan menyebabkan terjadinya penurunan kualitas pada minuman yogurt. Bahan penstabil yang umum digunakan untuk mempertahankan kualitas minuman yogurt adalah senyawa kimia yaitu carboxymethyl cellulose (CMC). Ganyong (Canna edulis Ker) berpotensi digunakan sebagai penstabil alami, serta merupakan umbi lokal asal Indonesia dengan kandungan pati yang tinggi dan memiliki nilai tambah senyawa antioksidan. Tujuan dari penelitian ini adalah untuk mengetahui efektivitas pati Ganyong sebagai substitusi penggunaan CMC terhadap aktivitas fisikokimia dan antioksidan dari minuman yogurt selama penyimpanan suhu dingin. Rancangan faktorial pola dua arah digunakan dalam penelitian ini dengan faktor pertama adalah 5 Kelompok perlakuan kadar pati Canna / CMC meliputi, T0 (0,2\% CMC) sebagai kontrol, T1 (0,15\% CMC + 0,025\% canna), T2 (0,1\% CMC + 0,05\% canna), T3 (0,05\% CMC + 0,075\% canna), dan T4 (0,1\% Canna). Faktor kedua adalah waktu penyimpanan minuman yogurt dibagi menjadi 4 kelompok meliputi 1, 7, 14 dan 21 hari, untuk mengetahui perubahan kualitas selama disimpan di lemari es pada suhu $4^{\circ} \mathrm{C}$. Data yang diperoleh dari hasil penelitian dianalisis menggunakan General Linear Model (GLM) dan dilanjutkan oleh Uji Jarak Berganda Duncan (UJBD). Hasil dari penelitian ini menunjukkan bahwa pati ganyong dapat digunakan sebagai penstabil alami yang dapat menghasilkan minuman yogurt fungsional dengan manfaat kesehatan terkait dengan aktivitas antioksidan yang baik. Kombinasi penggunaan 0,1\% CMC dan 0,05\% pati ganyong pada proses pembuatan minuman yogurt telah menghasilkan kualitas fisikokimia yang terbaik.

Kata kunci: aktivitas antioksidan, carboxymethyl cellulose, sineresis, umbi Ganyong, viskositas

\section{Introduction}

Yogurt market already provides many types of yogurt, including yogurt set, frozen yogurt, Greek yogurt, and yogurt drinks. Increasing the availability of various kinds of a yogurt drink with health benefits is expected to fulfill the increasing demand for yogurt in recent years. The benefits of yogurt were associated with its quality. Storage and cooling will lead to the release of water (syneresis) that will affect the protein dehydration and then decrease the end product quality (Tamime and Robinson, 2007). Enhancing and maintaining the desirable yogurt quality during storage such as texture, viscosity/consistency, appearance, and mouthfeel can be done with stabilizer addition. 
The type of stabilizer that commonly used by producers is carboxymethyl cellulose (CMC) as synthetic hydrocolloid which added into the yogurt. However, CMC will be accumulated in the human body with regular consumption, which will decrease the $\mathrm{pH}$ value of caecal and elevate the population of a non-digested microorganism (Juśkiewicz and Zduńczyk, 2004). Recently, the consumer has changed to healthier lifestyles that decide to reduce the used of synthetic materials into their diets. Consumers are more interested in food with high nutritional value, low in fats, rich in bioactive compounds, and negative association with the risk of disease(Waijers et al., 2007).

In 2006, Indonesia produced 500 tons of canna tubers in 2-harvests time, then processed into starch with the production capacity of approximately 50 tons per year, while the production would continuously increase $12.5 \%$ each year (Lestari et al., 2012). Canna tubers (Canna edulis Ker) provided high starch and had potential antioxidative properties that could be used as an alternative natural stabilizer to replace the application of CMC (Umam et al., 2018).

Canna starch contains $24.06 \%$ of amylose with the most useful function as a hydrocolloid that forms a gel after gelatination starch. In addition, There is $63.27 \%$ of amylopectin in Canna starch providing a high capability of water holding capacity and retrogradation. The combination of amylose and amylopectin led to an initial loss in viscosity with substantial effects on making a gel (Carolina and IImi, 2016). The existence of high levels antioxidants, flavonoids, and polyphenols was showed in Canna extracts (Mishra et al., 2011).

Therefore, the purpose of this study was to investigate the effects of replacing carboxymethyl cellulose (CMC) with Canna starch (Canna edulis Ker) as a natural stabilizer on the physicochemical and antioxidant activity of yogurt drink during cold storage, in order to utilize the native Indonesian stabilizer for a functional yogurt drink product.

\section{Materials and Method}

Yogurt drink was manufactured in Dairy Laboratory of Animal Science Department, National Pingtung University of Science and Technology, Taiwan.

\section{Canna starch preparation}

Indonesian Red Canna edulis Ker (aged 5-10 months) were obtained from local farmers (Tumpang, Malang, Indonesia). According to AOAC (1995), Canna tubers washed, cut, and treated with $7.5 \%$ saline solution for $1 \mathrm{~h}$ to remove oxalate compounds. The pieces of Canna were crushed and mixed with water in the ratio $1: 4$, then squeezed using filter cloth until resulted solid fractions. The solid was added with 1:4 of water and then filtered. Canna starch was precipitated for 6 hours -8 hours. The formed starch was dried at $60^{\circ} \mathrm{C}$ for 6 hours, then milled and sieved with a 100 mesh to obtain powdered starch.

\section{Preparation of yogurt drink}

'Preparation of all sample was done on the same day. Raw cows milk was mixed with $15 \%$ skim milk powder (Fonterra Co., Auckland, New Zealand) and added the CMC (Fortune Biotech, Hillsborough, USA) and Canna starch then divided into five groups were T0 $(0.2 \% \mathrm{CMC}), \mathrm{T} 1$ (0.15\% CMC + 0.025\% Canna starch), T2 (0.1\% CMC + 0.05\% Canna starch), T3 (0.05\% CMC + 0.075\% Canna starch), and T4 (0.1\% Canna starch). After samples had been mixed thoroughly, then heated at $85^{\circ} \mathrm{C}$ for $30 \mathrm{~min}$ and cooled to $43^{\circ} \mathrm{C}$. Pasteurized milk was inoculated with $2 \%$ of $S$. thermophilus 14086 and $L$. Bulgaricus 12297 (1:1 in ratio) (Chr. Hansen, Denmark) as yogurt starter culture. Samples were put into $1000 \mathrm{~mL}$ of a sterilized bottle and incubated at $37^{\circ} \mathrm{C}$ about $6-12$ hours until pH 4.6 was reached. Added the $1000 \mathrm{~mL}$ of $10 \mathrm{~g} / 100$ $\mathrm{ml}(\mathrm{w} / \mathrm{v})$ sugar solution when fermentation 
process was done, then stored in the refrigerator at $4^{\circ} \mathrm{C}$. The samples were collected to analyze during $1,7,14$, and $21 \mathrm{~d}$ of refrigerated storage.

\section{pH and titratable acidity (TA) determination}

Suntex pH Meter SP-2500 (Suntex Instruments Co., Ltd., New Taipei, Taiwan) that calibrated with buffer standards of $\mathrm{pH} 4$ and $\mathrm{pH}$ 7 was used to measure the $\mathrm{pH}$ value of yogurt samples. TA was expressed as \% lactic acid measured with the method of Sabadoš (1996) $8.8 \mathrm{~g}$ of yogurt sample prepared with $9 \mathrm{ml}$ of destilled water then added with $0.5 \mathrm{ml}$ of $1 \%(\mathrm{v} / \mathrm{v})$ phenolphthalein and titrated with $0.1 \mathrm{M}$ sodium hydroxide $(\mathrm{NaOH})$.

\section{Determination of syneresis and sedimentable fraction}

Syneresis and sedimentable fraction of each yogurt drink samples were measured using the method of Wu et al. (2013). An amount of $20 \mathrm{~g}$ yogurt sample was centrifuged (Hettich Centrifuger Universal 320R, Germany) 1200 rpm at $4^{\circ} \mathrm{C}$ for 20 minutes. The weight fraction of the supernatant recovered $(\% \mathrm{v} / \mathrm{w})$. The sedimentable fraction has the function to measure the stability was prepared an amount of $10 \mathrm{~g}$ yogurt sample was centrifuged 4000 $\mathrm{rpm}$ at $25^{\circ} \mathrm{C}$ for 20 minutes. The sedimentable fraction value was resulted by the ratio of the sediment weight to the sample weight. All measurements were performed in triplicate.

\section{Determination of viscosity}

According to Kasinos et al. (2014) Viscosity measurements were done at $24^{\circ} \mathrm{C}$ using $60 \mathrm{rpm}$ rotational viscometer (DV-II digital viscometer; Brookfield Engineering Laboratories, Inc, Middleboro, MA, USA) with spindle number 2 .

\section{Antioxidant activity}

According to Soleymanzadeh et al. (2016), whey fraction of yogurt sample was prepared before continued to DPPH radical scavenging activity analysis. An amount of $25 \mathrm{~mL}$ yogurt sample was placed in a centrifuge tube and centrifuged $9000 \mathrm{rpm}$ at $40 \mathrm{C}$ for 20 minutes (Eppendorf 5810R Multipurpose Centrifuges, Germany). The supernatant of the sample was filtered on a $0.45 \mu \mathrm{m}$ cellulose membrane filter (Toyo Roshi Kaisha, Ltd., Tokyo, Japan) using vacuum pump (Gast DOA-P104-AA Diaphragm Vacuum, IDEX Corp., Illinois, USA). DPPH radical solution $(0.002 \% \mathrm{w} / \mathrm{v})$ in $95 \%$ ethanol was prepared (Sigma-Aldrich, STBF1771V; St Louis, USA). A volume of $3600 \mu \mathrm{L}$ of DPPH in ethanol was added to $400 \mu \mathrm{L}$ of whey fraction with the concentration of $1.0 \mathrm{mg} / \mathrm{mL}-1$. The mixture was vortexed and left to stand for $30 \mathrm{~min}$ in the dark room. The reduction of the DPPH was determined using WPA Spectrawave - $\mathbf{8 0 0}$ Diode Array Spectrophotometer (Biochrom, Ltd., Cambridge, England) set to $517 \mathrm{~nm}$ of absorbance.

The antioxidant activity was expressed as percentage of DPPH activity calculated as :

$$
\begin{aligned}
& \text { inhibition }(\%)= \\
& {\left[\frac{\text { Absorbance Blank- Absorbance Sample }}{\text { Absorbance Blank }}\right] \times 100 \%}
\end{aligned}
$$

Where :

Absorbance blank: the absorbance of the control sample (DPPH solution without whey fraction)

Absorbance sample: the absorbance of test sample (DPPH solution plus whey fraction).

\section{Statistical analysis}

Data obtained from the results of subsequent studies analyzed by General Linear Model (GLM) in a Windows-based software package, SPSS for Windows version 16 . If there is any significant difference then continued by test using Duncan's Multiple Range Test (DMRT) at the $5 \%$ significance level $(\alpha=0.05)$.

\section{Results and Discussion}

\section{$\mathrm{pH}$ and titratable acidity}

Changes in $\mathrm{pH}$ values of yogurt with the different combination level of CMC and Canna starch during storage resulted in $\mathrm{pH}$ values 
ranged from $4.60 \pm 0.01$ to $4.35 \pm 0.01$. The different combination level addition of Canna starch and CMC showed significantly changed on $\mathrm{pH}$ values of yogurt drink $(p<0.05)$. The addition of $0.1 \%$ Canna starch (T4) resulted in the lowest average $\mathrm{pH}$ values about $4.47 \pm 0.01$, while $0.15 \% \mathrm{CMC}+0.025 \%$ Canna starch (T1) led the highest average $\mathrm{pH}$ values about $4.55 \pm 0.01$. Figure 1 showed that $\mathrm{pH}$ values of all treatment group were significantly $(p<0.05)$ decreased during 21 days of storage. The average $\mathrm{pH}$ value of yogurt drink at 1st day was 4.60 and decreased by $4.56,4.50$, and 4.42 for 7 th, 14 th, and 21st days, respectively. The results showed that post acidification continued during the storage period. Higher level addition of Canna starch resulted in lower $\mathrm{pH}$ values, and it indicated that Canna starch had become an energy source for metabolic activity of yogurt bacteria. Lactic acid is the most abundant component that produced by $L A B$ during the fermentation process of milk into yogurt. Lactic acid $\left(\mathrm{C}_{3} \mathrm{H}_{6} \mathrm{O}_{3}\right)$ readily dissociates into $\mathrm{H}^{+}$and $\mathrm{CH} 3 \mathrm{CHOHCOO}$ ions. Lactic acid produced by the $L A B$ in yogurt was increasing $\mathrm{H}+$ ion that resulted in the decreasing of $\mathrm{pH}$ values (Muniandy et al., 2017). Whereas Panesar and Shinde (2012) stated that residual carbohydrate utilization, the small amount of $\mathrm{CO}_{2}$, and formic acid from lactose might cause the decrease in $\mathrm{pH}$ during storage.
Titratable acidity (TA) values as \% lactic acid, significantly increased $(p<0.05)$ during storage when Canna starch added into the yogurt samples (Figure 1). The TA values ranged from $0.97 \pm 0.01$ to $1.17 \pm 0.01$. The addition of $0.1 \%$ Canna starch (T4) resulted in the highest average TA values about $1.05 \pm 0.01$, while $0.2 \%$ CMC (TO) resulted in the lowest average TA values approximately $0.97 \pm 0.01$. During the 21st day's storage period, adding higher concentrations of canna starch into yogurt samples resulted in a significant $(p<0.05)$ increase of the TA average values 0.92 to 1.10 , respectively.

The higher TA of yogurt with Canna starch was related to the amylose and amylopectin that may improve the metabolism or growth of the starter cultures, causing a higher production of acids. The high values for TA agreed with results from Seo et al. (2009) the reducing in $\mathrm{pH}$ and increasing of titratable acidity were showed during 15 days of storage in cholesterolreduced yogurt samples added with stabilizer from nanopowder chitosan. A similar result obtained from cholesterol-reduced yogurt added with enriched primrose oil that decreases in $\mathrm{pH}$ and increases in titratable acidity when stored at $4^{\circ} \mathrm{C}$ for 15 days (Lee et al., 2007).
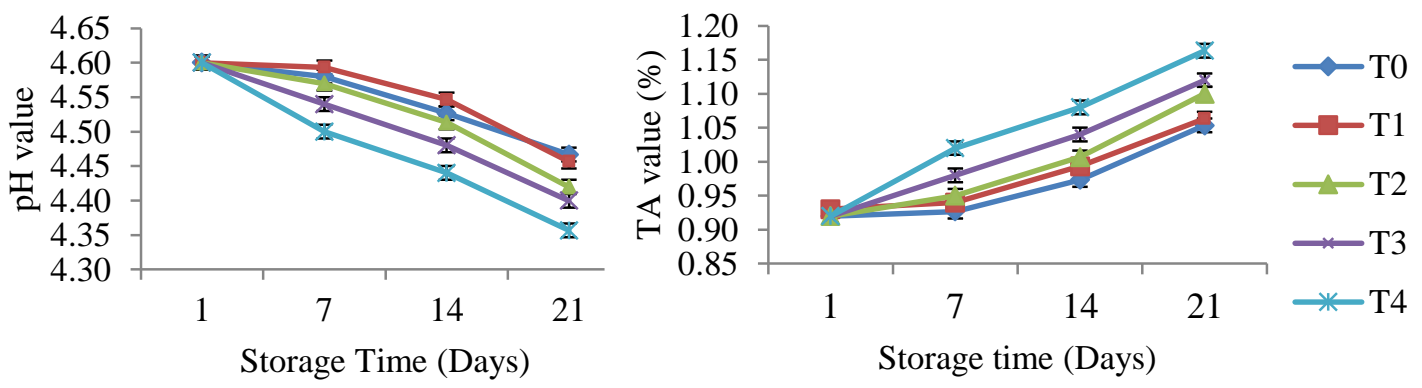

Note : T0 (0.2\% CMC), T1 (0.15\% CMC + 0.025\% Canna), T2 (0.1\% CMC + 0.05\% Canna), T3 (0.05\% CMC + 0.075\% Canna), and T4 (0.1\% Canna). Samples were stored at $4{ }^{\circ} \mathrm{C}$.

Figure 1 Interaction between addition level of canna starch and $\mathrm{CMC}$ on $\mathrm{pH}$ value and titratable acidity during storage $(p<0.05)$. Error bars represent standard deviation. 
There was a significant difference in interaction between treatment group and storage time $(p<0.05)$ on $\mathrm{pH}$ and TA value. A Significant decrease in $\mathrm{pH}$ and increase in TA value during 21 days of the storage will adversely affect the yogurt quality such as increase the syneresis rate, reduce the stability, and potentially for spoilage bacteria contamination. Fox et al. (2017) stated that syneresis was closely related to acidity however inversely related to $\mathrm{pH}$. The more significant changes in $\mathrm{pH}$ and titratable acidity will affect the faster post acidification that reduced the storage stability of yogurt product (Kim et al., 2012). The decrease in $\mathrm{pH}$ influenced by interactions between yogurt culture bacteria and spoilage microorganisms present in the product (Dzigbordi et al., 2013).

Syneresis. Syneresis is closely related to casein micelle network condition. Syneresis value of

Table 1 Interaction between combination addition level of Canna starch and CMC on syneresis,

sedimentable fraction and viscosity of yogurt drink during storage

\begin{tabular}{|c|c|c|c|c|c|}
\hline \multirow{2}{*}{ Treatments } & \multicolumn{4}{|c|}{ Storage time } & \multirow{2}{*}{ Mean \pm SD } \\
\hline & 1 & 7 & 14 & 21 & \\
\hline \multicolumn{6}{|l|}{ Syneresis (\%) } \\
\hline T0 & $31.25 \pm 0.87$ & $21.88 \pm 0.60$ & $27.56 \pm 0.63$ & $23.89 \pm 0.54$ & $26.15 \pm 3.65^{\mathrm{e}}$ \\
\hline $\mathrm{T} 1$ & $23.01 \pm 0.24$ & $18.70 \pm 0.61$ & $20.33 \pm 0.73$ & $19.55 \pm 0.57$ & $20.40 \pm 1.75^{c}$ \\
\hline $\mathrm{T} 2$ & $22.33 \pm 0.38$ & $16.02 \pm 0.23$ & $18.48 \pm 0.74$ & $16.91 \pm 0.50$ & $18.43 \pm 2.56^{\mathrm{a}}$ \\
\hline T3 & $24.80 \pm 0.74$ & $16.80 \pm 0.86$ & $18.82 \pm 0.66$ & $17.71 \pm 0.88$ & $19.53 \pm 3.33^{\mathrm{b}}$ \\
\hline T4 & $32.94 \pm 0.58$ & $17.82 \pm 0.86$ & $21.00 \pm 0.48$ & $18.66 \pm 0.50$ & $22.61 \pm 6.37^{d}$ \\
\hline Mean $\pm S D$ & $26.87 \pm 4.49^{d}$ & $18.24 \pm 2.18^{a}$ & $21.24 \pm 3.46^{c}$ & $19.34 \pm 2.58^{\mathrm{b}}$ & \\
\hline \multicolumn{6}{|c|}{ Sedimentable fraction (\%) } \\
\hline T0 & $0.73 \pm 0.03$ & $0.70 \pm 0.02$ & $0.67 \pm 0.01$ & $0.64 \pm 0.01$ & $0.69 \pm 0.04^{a}$ \\
\hline $\mathrm{T} 1$ & $0.73 \pm 0.04$ & $0.66 \pm 0.02$ & $0.65 \pm 0.01$ & $0.63 \pm 0.01$ & $0.67 \pm 0.04^{b}$ \\
\hline $\mathrm{T} 2$ & $0.70 \pm 0.01$ & $0.66 \pm 0.02$ & $0.66 \pm 0.01$ & $0.62 \pm 0.04$ & $0.66 \pm 0.04^{b}$ \\
\hline T3 & $0.67 \pm 0.01$ & $0.67 \pm 0.01$ & $0.66 \pm 0.01$ & $0.63 \pm 0.01$ & $0.66 \pm 0.02^{b}$ \\
\hline T4 & $0.66 \pm 0.01$ & $0.69 \pm 0.02$ & $0.66 \pm 0.01$ & $0.65 \pm 0.01$ & $0.67 \pm 0.02^{b}$ \\
\hline Mean $\pm S D$ & $0.70 \pm 0.04^{\mathrm{a}}$ & $0.67 \pm 0.02^{b}$ & $0.66 \pm 0.01^{c}$ & $0.63 \pm 0.02^{d}$ & \\
\hline \multicolumn{6}{|l|}{ Viscosity (cP) } \\
\hline T0 & $77.17 \pm 1.26$ & $94.67 \pm 1.26$ & $105.50 \pm 3.97$ & $110.67 \pm 4.04$ & $97.00 \pm 13.63^{a}$ \\
\hline $\mathrm{T} 1$ & $84.83 \pm 3.55$ & $110.83 \pm 7.01$ & $151.50 \pm 2.65$ & $157.00 \pm 6.50$ & $126.04 \pm 31.38^{b}$ \\
\hline $\mathrm{T} 2$ & $89.00 \pm 2.29$ & $119.33 \pm 1.04$ & $154.50 \pm 6.14$ & $160.83 \pm 8.13$ & $130.92 \pm 30.52^{c}$ \\
\hline T3 & $87.17 \pm 1.04$ & $106.50 \pm 4.77$ & $183.00 \pm 1.32$ & $169.50 \pm 4.77$ & $136.54 \pm 42.48^{d}$ \\
\hline $\mathrm{T} 4$ & $81.68 \pm 2.78$ & $109.83 \pm 2.84$ & $209.67 \pm 3.82$ & $203.33 \pm 6.05$ & $151.11 \pm 58.91^{\mathrm{e}}$ \\
\hline Mean $\pm S D$ & $83.97 \pm 4.78^{a}$ & $108.23 \pm 8.96^{b}$ & $160.83 \pm 36.20^{c}$ & $160.27 \pm 31.17^{c}$ & \\
\hline
\end{tabular}

Note : T0 (0.2\% CMC), T1 (0.15\% CMC + 0.025\% Canna), T2 (0.1\% CMC + 0.05\% Canna), T3 (0.05\% CMC + 0.075\% Canna), and T4 ( $0.1 \%$ Canna). Samples were stored at $40 \mathrm{C}$. Mean in the same row and column with different superscripts differ significantly $(p<0.05)$. yogurt drink with Canna starch was significantly lower $(p<0.05)$ than yogurt drink with $C M C$ during cold storage (Figure 23). In the group treatment 2 (T2), which was added with $0.1 \%$ $\mathrm{CMC}+0.05 \%$ Canna starch, syneresis rate decreased by $28.2 \%$ from $22.33 \%$ to $16.02 \%$ on 7 th days, increased by $15.3 \%$ to $18.48 \%$ on 14 th days, then gradually reduced by $8.5 \%$ to $16.91 \%$ on 21st days, respectively. By comparison, in control, which was added with $0.2 \% \mathrm{CMC}$, syneresis rate decreased by $30 \%$ from $31.25 \%$ to $21.88 \%$ on 7 th days, increased by $25.9 \%$ to $27.56 \%$ on 14 th days, then reduced by $13.34 \%$ to $23.89 \%$ on 21st days, respectively. Mainly, in all treatments were added Canna starch, the changes in syneresis values were found to be much lower compared to the control (Table 1). 
The results indicated that Canna starch was adequate to reduce the syneresis during storage. Starch in Canna composed of high amylopectin content about $63.27 \%$ that have the capability of water holding capacity to reduce the risk of syneresis. According to (Hongyu et al., 2000), water holding the capacity reflected the ability of the protein to hold on water inside the yogurt structure. Amylopectin with longer chain length was stronger in gelforming when amylose and amylopectin were mixed (Bertoft et al., 2016).

The decreased syneresis during storage in this experiment is accepted with Ares et al. (2007) significantly result of sensory properties, texture quality, and syneresis rate was found when sweetened plain-stirred yogurt added with starch and gelatin. In addition, wheying-off will reduce the consumer preference of yogurt product, and it caused by the perception of something microbiologically wrong in the manufacturing process. Several kinds of the stabilizer such as starch, gelatin, and pectin should be added by the manufacturer to prevent wheying-off in yogurt product (Lee and Lucey, 2006)

There was a significant difference of interaction between treatment group on storage time $(p<0.05)$, the addition of Canna starch with a different percentage will decrease the syneresis value of yogurt drink over 21st storage days. Duncan Multiple Range Test (DMRT) at 5\% significance level performed, yogurt drink added with the combination of $0.1 \%$ CMC and $0.05 \%$ Canna starch with an average value $18.43 \pm 0.18 \%$ selected as the best treatment.

\section{Sedimentable fraction}

Table 1 showed the sedimentable fraction of yogurt with Canna starch and CMC added after 21 days of storage. On day 1 , the $0.1 \%$ Canna starch (T4) showed the lowest sedimentable fraction value of $0.66 \%$, which was significantly lower $(p<0.05)$ than the others samples. Whereas, yogurt with the addition of $0.2 \% \mathrm{CMC}$
(T0) and 0.15\% CMC + 0.025\% Canna starch (T1) with values $0.73 \%$ had the highest amount of sedimentable fraction, which was significantly higher $(p<0.05)$ than the other samples. After 21 days, $0.05 \% \mathrm{CMC}+0.075 \%$ Canna (T3) samples had the lowest sedimentable fraction of $0.62 \%$, followed by $\mathrm{T} 3$ and $\mathrm{T} 1, \mathrm{~T} 0$ and $\mathrm{T} 4$ samples with the value of $0.63 \%, 0.64 \%$, and $0.65 \%$ respectively.

The addition of Canna starch and CMC resulted in low quantities of sedimentable fraction, it indicates the stability of milk proteins under acidic conditions was good. The results were in agreement with Wu et al. (2013) the increasing level addition of CMC will increase the stability of acidified whole milk during storage. Whey separation and protein aggregation occurred when casein close to the isoelectric points, adding the stabilizer is one of the several ways to solve that problem. The unstable sample showed larger casein aggregates. However, the addition of higher $\mathrm{CMC}$ will reduce the sedimentation of yogurt drinks because of the casein micelles electrosorption (Wu et al., 2014)

On the other hand, the decreasing of the sedimentable fraction of yogurt samples that containing different combination level of Canna starch and $\mathrm{CMC}$ was related to the increase in the viscosity. The interaction between stabilizer and casein particles thus contributing a strong gel that improved the viscosity and maintains the protein stability. The high molecular weight of starch was interacted with casein to form a casein-starch system that increases the waterbind capacity to improve the rheological properties of yogurt (Damian et al., 2017)

There was a significant difference of interaction between treatment group on storage time $(p<0.05)$, the addition of Canna starch with a different percentage will reduce the sedimentable value of yogurt drink over 21st storage days. Duncan Multiple Range Test (DMRT) at 5\% significance level was performed, yogurt drink added with $0.1 \% \mathrm{CMC}+0.05 \%$ 
Canna starch and 0.05\% CMC + 0.075\% Canna starch with an average value $0.66 \%$ selected as the best treatment.

\section{Viscosity}

The viscosity of yogurt drink was significantly increased $\quad(p<0.05) \quad$ with increasing concentrations levels of Canna starch added (Table 1). The initial viscosity value of each treatment on 1st storage day was $84.83 \mathrm{cP}$ (T1), $89.00 \mathrm{cP}(\mathrm{T} 2), 87.17 \mathrm{cP}(\mathrm{T} 3)$, and $81.68 \mathrm{cP}(\mathrm{T} 4)$ respectively, as compared with control samples 77.17 CP. The viscosity value of all group with the combination of CMC and Canna starch was significantly increased after 14 days storage. The viscosity value of each treatment increased by 36.7\% (T1), 29.5\% (T2), 71.8\% (T3), and 90.9\% (T4) respectively. However, at the end of the storage period, the viscosity value of T3 and T4 were decreased to $169.50 \mathrm{cP}$ and $203.33 \mathrm{cP}$.

There was a significant difference of interaction between treatment group on storage time $(p<0.05)$, the addition of Canna starch with a different percentage will increase the viscosity value of yogurt drink over 21st storage days. The increasing viscosity value was related to the longer acidification process and lower final $\mathrm{pH}$ of yogurt drink during post acidification when the higher Canna starch was added. According to Beal et al. (1999), longer acidification time has resulted in highest viscosity, and it means that fermentation time had a positive effect on texture development. Postacidification has occurred during storage at $4^{\circ} \mathrm{C}$ which decreased the $\mathrm{pH}$ value that caused by the persistent metabolic activity of lactic acid bacteria. Storage period and final fermentation $\mathrm{pH}$ value resulted in the significant effect of the total bacteria, post acidification, and texture. The low finished $\mathrm{pH}$ and fermentation temperature produced the yogurt with the highest viscosity.

The viscosity results in this experiment were similar to Khalifa and Ibrahim (2015) the addition of $0.5-1.5 \%$ modified starch significantly increased the viscosity and reduce the serum separation of camel's milk yogurt, it caused by interactions between casein particles and modified starch. The polysaccharide-protein association might have more impact on the viscosity than the protein-protein interactions of non-ropy yogurt (Tamime and Robinson, 2007)

\section{Antioxidant activity}

The antioxidant activity of yogurt drink with the different level of Canna starch and CMC addition is shown in Figure 2. The presence of Canna starch in yogurt drink showed significant different $(p<0.05)$ in \%DPPH value compared to yogurt with $\mathrm{CMC}$ over 21 days of storage. The antioxidant activity values ranged from $61.73 \%$ to $85.27 \%$. The addition of $0.1 \%$ Canna starch (T4) resulted in the highest average antioxidant values $80.18 \%$, while $0.2 \%$ CMC (TO) led the lowest average antioxidant values about $70.69 \%$. On the other hand, prolonged refrigerated storage significantly changed $(p<0.05)$ \%DPPH value. The \%DPPH value at 21 storage days of all treatments was reduced to $10.1 \%$ (T1), $12.1 \%$ (T2), $11.4 \%$ (T3), and 5.5\% (T4) were compared to control group as the highest reducing value $25.2 \%$.

Higher \% DPPH indicated a great antioxidant activity of the product. DPPH measured indicated the ability of antioxidants to inhibit free radicals by donating a hydrogen atom. Antioxidant activity contributes to free radical scavenging nature to prevent atom hydrogenate (Sathisha et al., 2011). The higher antioxidant activity of yogurt drink with Canna starch was related to the phenolic compound of Canna starch. Phenolic content in the plant is the most influential factor in antioxidant activity (Ainsworth and Gillespie, 2007). 


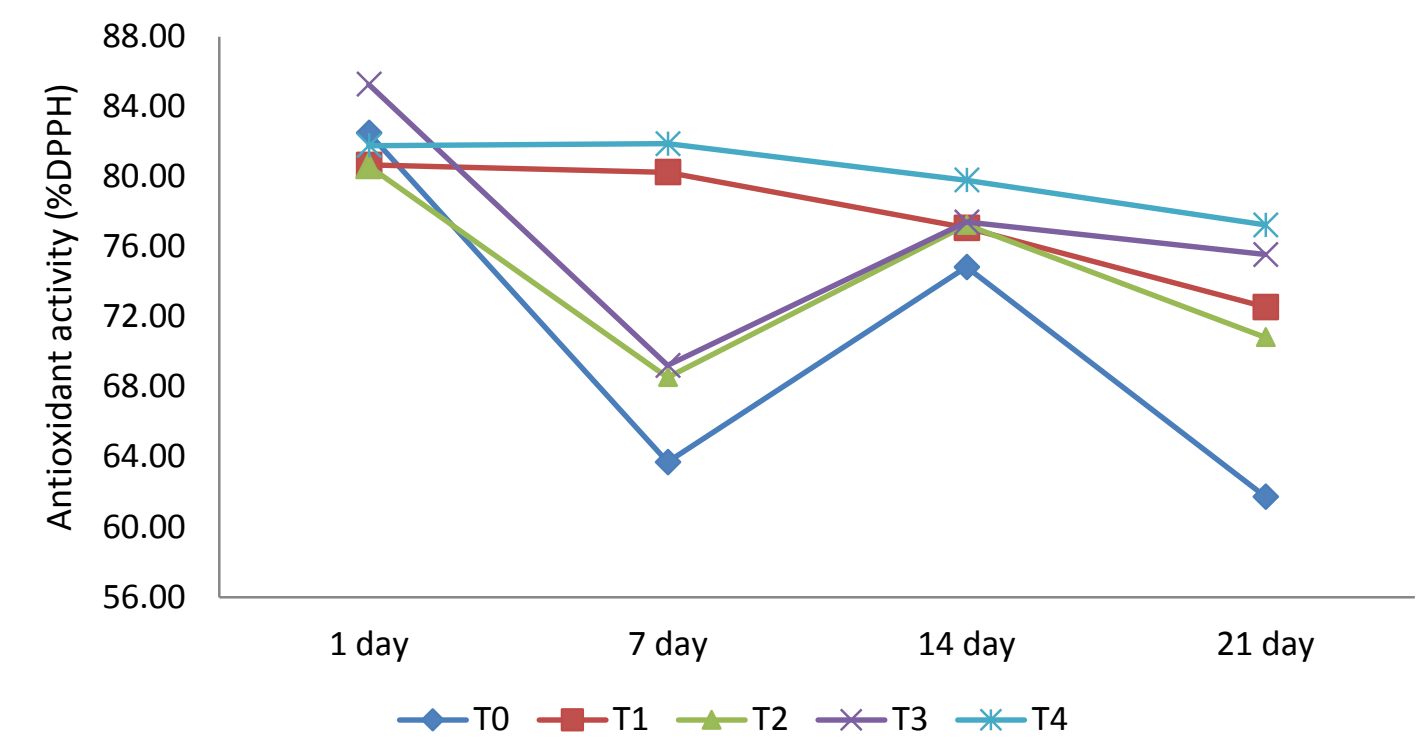

Note : T0 (0.2\% CMC), T1 (0.15\% CMC + 0.025\% Canna), T2 (0.1\% CMC + 0.05\% Canna), T3 (0.05\% CMC + 0.075\% Canna), and T4 (0.1\% Canna). Samples were stored at $4^{\circ} \mathrm{C}$.

Figure 2 Interaction between addition level of Canna starch and CMC on antioxidant activity (\%DPPH) during storage $(p<0.05)$. Error bars represent standard deviation.

The other reason that made yogurt with Canna resulted in higher antioxidant activity is Canna starch could improve the lactic acid bacteria metabolic activity. The higher carbohydrate content (97.88\%) in Indonesian native Canna starch (Carolina and IImi, 2016) resulted in higher lactic acid during fermentation. Initially, lactic acid bacteria applied in a traditional fermentation process that had several steps. First, starch was extracted and then hydrolyzed with enzymes into simple sugars. Lactic acid produced by lactic acid bacteria is derived from the fermentation process of glucose as simple sugars that resulted from hydrolysis (Datta and Henry, 2006). According to Shori and Baba (2012), metabolic activity of lactic acid bacteria play an essential role in producing organic acids during fermentation and refrigerated storage. The amount organic acids and milk protein proteolysis could be the other sources that affected antioxidant activities in yogurt product. Yogurts added with Canna starch showed the potential health benefits related to high antioxidant activity and bacterial viability.

The antioxidant activity result of this experiment showed a difference with previous research. According to Tomovska et al. (2016), the antioxidant activity resulted from the combination between $\mathrm{L}$. bulgaricus and $\mathrm{S}$. thermophillus were ranged from $52.44 \%$ to $47.42 \%$ during 15 days of storage. The difference of the values for the antioxidant activity may also be dependent on the several factors such as the culture condition, raw material quality, and additional ingredients. Moreover, the conditions in the laboratory during the examinations such as where the fermentation takes place, the sensitivity of instruments used and the sanitary conditions.

There was a significant difference of interaction between treatment group on storage time $(p<0.05)$, the addition of Canna starch with a different percentage has the ability to increase the antioxidant activity of yogurt drink over 21st storage days.

\section{Conclusions}

Canna starch has the capability as a natural stabilizer for producing functional yogurt drink with potential health benefits related to the high antioxidant activity. The combination of $0.1 \%$ CMC and $0.05 \%$ Canna starch addition on yogurt 
drink manufacture showed the best physicochemical quality.

\section{Acknowledgement}

Authors would like to thank Double Degree Program of Brawijaya University and National Pingtung University of Science and Technology for supported this research. We also would like to acknowledge the support of all the Dairy Laboratory members of Animal Science Department for their assistance to finish this experiment.

\section{References}

Ainsworth EA and KM Gillespie. 2007. Estimation of total phenolic content andother oxidation substrates in plant tissues using Folin-Ciocalteu reagent. Nature Protocols. 2 (4).

AOAC. 1995. Official methods of analysis. In AOAC international. Vol 2. Arlington: VA: Association of Analytical Communities.

Ares G, D Gonçalvez, C PÉrez, G Reolón, N Segura, P Lema and A Gámbaro. 2007. Influence of gelatin and starch on the instrumental and sensory texture of stirred yogurt. International Journal of Dairy Technology. 60 (4): 263-269.

Beal C, J Skokanova, E Latrille, N Martin and G Corrieu. 1999. Combined effects of culture conditions and storage time on acidification and viscosity of stirred yogurt. Journal of Dairy Science. 82 (April): 673-681.

Bertoft E, GA Annor, X Shen, P Rumpagaporn, K Seetharaman and BR Hamaker. 2016. Small differences in amylopectin fine structure may explain large functional differences of starch. Carbohydrate Polymers. 140: 113-121.

Carolina A and FN Ilmi. 2016. Production of Indonesian Canna edulis type IV resistant starch through acetylation modification. International Food Research Journal. 23 (2): 491-497.

Damian C, M-A Oroian, A Leahu and I Cioarbă. 2017. Effect of addition of starch and agar-agar on rheological behaviour of yogurt. Food and Environment Safety Journal. 11 (1): 97-102.

Datta $R$ and M Henry. 2006. Lactic acid: recent advances in products, processes and technologies - a review. Journal of Chemical Technology and Biotechnology. 81 (7): 1119-1129.

Dzigbordi B, J Adubofuor and WM Faustina Dufie. 2013. The effects of different concentrations of natamycin and the point of addition on some physicochemical and microbial properties of vanilla-flavoured yoghurt under refrigerated condition. International Food Research Journal. 20 (6): 3287-3292.

Fox PF, TP Guinee, TM Cogan and PLH McSweeney. 2017. Fundamentals of cheese science. 2nd ed. New York, USA: Springer US.

Hongyu W, GJ Hulbert and JR Mount. 2000. Effects of ultrasound on milk homogenization and fermentation with yogurt starter. Innovative Food Science and Emerging Technologies. 1 (3): 211218.

Juśkiewicz J and Z Zduńczyk. 2004. Effects of cellulose, carboxymethylcellulose and inulin fed to rats as single supplements or in combinations on their caecal parameters. Comparative Biochemistry and Physiology - A Molecular and Integrative Physiology. 139 (4): 513-519.

Kasinos M, T Tran Le and P Van der Meeren. 2014. Improved heat stability of recombined evaporated milk emulsions upon addition of phospholipid enriched dairy by-products. Food Hydrocolloids. 34: 112-118.

Khalifa SA and AH Ibrahim. 2015. Influence of addition modified starches as stabilizer on physicochemical and textural properties of camel ' s milk yoghurt. Zagazig J. Agric. Res. 42 (2): 295307.

Kim JK, JS Lee, YT Jeong and IH Bae. 2012. Development of yoghurt with Sanmeoru (Vitis amurensis Ruprecht) wine as an additive. Korean J Dairy Sci Technol. 30: 23-30.

Lee SJ, JH Hwang, S Lee, J Ahn and HS Kwak. 2007. Property changes and cholesterol-lowering effects in evening primrose oil-enriched and cholesterolreduced yogurt. International Journal of Dairy Technology. 60 (1): 22-30.

Lee $\mathrm{W}$-J and JA Lucey. 2006. Impact of gelation conditions and structural breakdown on the physical and sensory properties of stirred yogurts. Journal of Dairy Science. 89 (7): 2374-2385.

Lestari ER, N Hidayat, I Purwaningsih, W Agustin and $P$ Dania. 2012. The improvement of roduction tecnique on agroindustry. Canna edulis Starch 2 (9): 8574-8578.

Mishra T, AP Das and A Sen. 2012. Phytochemical screening and In-vitro antioxidant profiling of solvent fractions of canna edulis ker gawler. Free Radicals and Antioxidants. 2 (1): 13-20.

Mishra T, AK Goyal, SK Middha and A Sen. 2011. Antioxidative properties of Canna edulis KerGawl. Indian Journal of Natural Products and Resources. 2 (3): 315-321.

Muniandy P, AB Shori and AS Baba. 2017. Comparison of the effect of green, white and black tea on Streptococcus thermophilus and Lactobacillus spp. in yogurt during refrigerated storage. Journal of the Association of Arab 
Universities for Basic and Applied Sciences. 22: 26-30.

Panesar PS and C Shinde. 2012. Effect of storage on syneresis, $\mathrm{pH}$, Lactobacillus acidophilus count, Bifidobacterium bifidum count of aloe vera fortified probiotic yoghurt. Current research in dairy sciences. 4 (1): 17-23.

Sabadoš D. 1996. Control and assessment of quality milk and dairy products 2nd Edn. Zagreb. Croatian Dairy Union.: 166-169.

Sathisha AD, HB Lingaraju and KS Prasad. 2011. Evaluation of antioxidant activity of medicinal plant extracts produced for commercial purpose. E-Journal of Chemistry. 8 (2): 882-886.

Seo MH, SY Lee, YH Chang and HS Kwak. 2009. Physicochemical, microbial, and sensory properties of yogurt supplemented with nanopowdered chitosan during storage. Journal of Dairy Science. 92 (12): 5907-5916.

Shori AB and AS Baba. 2012. Viability of lactic acid bacteria and sensory evaluation in Cinnamomum verum and Allium sativum-bio-yogurts made from camel and cow milk. Journal of the Association of Arab Universities for Basic and Applied Sciences. 11 (1): 50-55.

Soleymanzadeh N, S Mirdamadi and M Kianirad. 2016. Antioxidant activity of camel and bovine milk fermented by lactic acid bacteria isolated from traditional fermented camel milk (Chal). Dairy Science and Technology. 96 (4): 443-457.

Tamime AY and RK Robinson. 2007. Yogurt science and technology. Abington Hall, Abington, Cambridge CB21 6AH, England: Woodhead Publishing Limited.

Tomovska J, N Gjorgievski and B Makarijoski. 2016. Examination of $\mathrm{pH}$, titratable acidity and antioxidant activity in fermented milk. Journal of Materials Science and Engineering A. 6: 326-333.

Umam AK, LE Radiati, M Lin, S Peng, V Street, E Java, V Street and E Java. 2018. The utilization of canna starch ( Canna edulis Ker .) as an alternative hydrocolloid on the manufacturing process of yogurt drink. Animal Product Technology Journal. 13 (1): 1-13.

Waijers PMCM, EJM Feskens and MC Ocké. 2007. A critical review of predefined diet quality scores. British Journal of Nutrition. 97 (2): 219-231.

Wu J, B Du, J Li and H Zhang. 2014. Influence of homogenisation and the degradation of stabilizer on the stability of acidified milk drinks stabilized by carboxymethylcellulose. LWT - Food Science and Technology. 56 (2): 370-376.

Wu J, J Liu, Q Dai and H Zhang. 2013. The stabilisation of acidified whole milk drinks by carboxymethylcellulose. International Dairy Journal. 28 (1): 40-42.

Zhang J, ZW Wang and Q Mi. 2011. Phenolic compounds from Canna edulis Ker residue and their antioxidant activity. LWT - Food Science and Technology. 44 (10): 2091-2096. 